\title{
Ulama Dan Wacana Islam Dalam Hubungan Intelektual Di Tanah Melayu Dan Indonesia
}

\author{
Badlihisham Mohd Nasira ${ }^{\mathrm{a}}$, Rahimin Affandi Abd. Rahim ${ }^{\mathrm{b}}$, \& Khafidz Hamzah \\ a Profesor of Islamic Civilization, Fakulti Tamadun Islam, Universiti Teknologi Malaysia, 81310 UTM \\ ${ }^{b}$ Akademi Pengajian Islam, Universiti Malaya, Lembah Pantai 50603, Kuala Lumpur. \\ ${ }^{c}$ Akademi Pengajian Islam, Universiti Malaya, Lembah Pantai 50603, Kuala Lumpur. \\ *Corresponding author: badlihisham@utm.my
}

\author{
Article history \\ Received: 2014-07-09 \\ Received in revised form: 2014-11-27 \\ Accepted: 2014-11-27
}

\begin{abstract}
This article is about the Islamic discourse upon the role of ulama and intellectual relationship in enriching the Muslim civilization in Malaysia and Indonesia. At the outset, it will explore the significant of Malay-Muslim civilization as well as the major role play by ulama in the development of Muslim civilization in Malay Archipelago. Besides, for the specification purpose it will concentrate on several issues pertaining to the main focus, namely; the Terengganu's Batu Bersurat, the Kaum Muda-Tua discourse in 1930s, the dakwah movement in 1970s and the Islamization of knowledge. Finally we may sum up that those intellectual discourses had enrich the Malay-Muslim knowledge resources in coping with the force modernization initiated by western power in the Malay Archipelago.
\end{abstract}

Keywords: Ulama, Kaum Muda-Tua, Batu Bersurat Terengganu, Dakwah, Islamization of Knowledge. 


\subsection{PENGENALAN}

Mengikut sejarawan, agama berperanan besar dalam membina sesuatu dunia. Hal ini tidak terkecuali dengan sejarah Tanah Melayu memandangkan agama Hindu-Budhha pernah membina tamadun di Tanah Melayu. Menurut M. Rajantheran (2001:49-50), tamadun binaan agama Hindu-Budhha ini agak eksklusif sifatnya (berasaskan sistem kasta) kerana lebih tertumpu kepada golongan raja dan bangsawan tanpa melibatkan masyarakat bawahan. Fenomena ini kemudiannya berubah dengan berlakunya proses kedatangan Islam ke Tanah Melayu. Kesannya, Islam berjaya memajukan daya intelektual masyarakat secara keseluruhan dan mewujudkan masyarakat yang lebih egalitarian. Lebih penting lagi Islam telah mengubah world-view masyarakat Melayu kepada world-view tauhid. Hal ini berlaku dengan wujudnya mekanisme pendidikan Islam yang dibangunkan oleh para mubaligh yang awal. Rentetan daripada itu, muncullah sejumlah ulama yang berperanan besar dalam memajukan tamadun di Tanah Melayu. Atas premis tersebut maka artikel ini cuba menganalisis peranan ulama dalam pembinaaan tamadun di Tanah Melayu. Oleh itu, beberapa fokus dan tema telah dipilih yang membabitkan isu hubungan intelektual antara ulama Malaysia dan Indonesia.

\subsection{ASAS DAN KEPENTINGAN SESUATU TAMADUN}

Sarjana menegaskan bahawa terdapat beberapa kepentingan tamadun;

Pertama, mewujudkan perpaduan untuk mengekalkan hayat sesuatu masyarakat. Pada pandangan Ibnu Khaldun, umur sesebuah tamadun secara hukum alami akan melalui tiga tahap yang utama; iaitu tahap kelahiran, kemajuan, dan kemunduran (Saleh Faghizadeh, 2004: 63-68). Atas dasar itu, kajian dan usaha penambahbaikan perlu dilakukan melalui kajian ilmiah untuk memanjangkan usia sesebuah tamadun. Oleh itu, Ibnu Khaldun telah memperkenalkan disiplin sosiologi-sejarah yang bertujuan untuk meneliti hukum alami fenomena sesebuah masyarakat, sama ada menafsirkan sesuatu fenomena sosial masyarakat dalam bentuk perkaitan sebab-musabab (Toto Suharto, 2003: 87-103) ataupun meramalkan jalan penyelesaian terhadap sesuatu permasalahan yang timbul (Abdullah Mohd Said, 2003). Bagi Ibnu Khaldun penggunaan disiplin sosiologi-sejarah ini tidak boleh dibuat secara spekulatif (agakan) semata-mata, tetapi perlu dilakukan secara berhemah. Ia perlu berasaskan kerangka kajian ilmiah yang bersifat objektif, mementingkan sumber kajian yang tepat, tafsiran sumber yang betul dan pengaplikasian metodologi kajian kes (observasi) yang betul (Mahayudin Haji Yahya, 1999: 10-11). Penggunaan disiplin sosiologi-sejarah yang ketat ini bermatlamatkan untuk memahami realiti sebenar perubahan masyarakat yang berlaku dan menawarkan ramalan penyelesaian masalah terhadap apa-apa masalah sosial yang timbul.

Kedua, tamadun atau pembangunan menyediakan manfaat keperluan asasi kepada ahli masyarakat. Terdapat kayu ukur bagi menilai kejayaan ataupun kegagalan sesuatu program pembangunan, iaitu;

- Adakah agihan pendapatan negara dapat dibahagikan secara seimbang kepada semua lapisan masyarakat? (Chamhuri Siwar, 2002: 119-145).

- Adakah program pembangunan dapat menyediakan keperluan asas kepada rakyat seperti life-sustenance (makanan, perumahan, kesihatan, dan perlindungan), self-esteem (peluang pekerjaan, pendidikan yang bermutu, dan kemajuan sosio-budaya), dan freedom from servitude (kebebasan individu untuk memilih dan bebas daripada sebarang belenggu dan pergantungan kepada orang lain) (Abdul Rahman Aziz, 2004, 1922).

- Adakah nikmat ataupun manfaat yang diharapkan daripada program pembangunan diterima atau tidak oleh golongan sasaran? (Che Su Mustaffa, 1996: 69-80).

- Adakah program pembangunan dapat memupuk semangat jati diri, perpaduan dan patriotisme dalam kalangan rakyat? (Abdul Rahman Aziz, 2004).

- Adakah program pembangunan dapat menjaga keseimbangan ekologi? (Rumaya Juhari, 2004: 10-16).

Ketiga, tamadun bakal mewariskan kepada generasi pelapis sistem nilai dan agama yang diamalkan oleh masyarakat. Hal ini termasuk penggunaan akal untuk menangani alam sehingga melahirkan kearifan tempatan. Namun, kearifan tempatan bukanlah membawa maksud local genius (kepandaian tempatan) yang kerap digunakan oleh sarjana Barat. Perkataan Arif ini membawa maksud mengetahui secara mendalam ataupun bijaksana kerana 
didasarkan kepada pemikiran yang mendalam. Ia biasa digunakan untuk melambangkan kebijaksanaan seseorang yang mencapai maqam al-Arifin.

Berbanding dengan neraca Barat, tradisi golongan arif atau intelektual Melayu-Islam boleh dirujuk kepada golongan ulama, ketua dan pemimpin masyarakat. Mereka biasanya bertindak dalam beberapa kapasiti yang khusus, merangkumi;

- Sebagai pemikir, pendidik dan pengatur hubungan masyarakat agar menjadi lebih harmonis dan mengelakkan huru-hara.

- Manusia Rabbani yang mengaitkan hubungan dengan alam, masyarakat, dan Allah.

- Pemikir yang responsif dengan realiti semasa.

- Pemikir yang berinteraksi dengan alam sehingga melahirkan konsep pengalaman (berguru dan belajar dengan alam) (Rahimin Affandi Abd Rahim, 2011).

Konsep kearifan tempatan ini bersesuaian dengan teori bahawa setiap manusia memiliki keupayaan akal untuk membina tamadun sendiri. Ia memerlukan elemen bantuan pengaruh asing atau sumber daripada luar diri manusia dan akal untuk maju. Ia membabitkan ilham dan laduni daripada Allah. Di sini letaknya peranan Allah dalam membekalkan akal dan alat (alam dan makhluk tunduk kepada manusia) untuk membantu manusia membangunkan tamadun. Seperti halnya direkodkan peranan Hims (Nabi Idris) dalam mengajar pelbagai ilmu kepada manusia awal sehingga menjadi asas tamadun awal Timur Tengah. Jelasnya, proses berfikir memerlukan imput, sumber, dan alat bagi membolehkan manusia berfikir dengan baik. Gabungan antara akal dan hubungan dengan Allah (sumber tasawuf) akan melahirkan kebijaksanaan kepada manusia (Rahimin Affandi Abd Rahim, 2013, 223-245).

Hal ini kemudiannya telah melahirkan epistemologi ilmu kepada masyarakat Melayu. Tidak keterlaluan jika dikatakan bahawa epistemologi masyarakat Melayu terdiri daripada beberapa perkara yang utama;

- $\quad$ Bentuk Bayani (bergantung kepada teks wahyu), Burhani (bergantung kepada akal), dan Irfani (bergantung pada intuisi dan ilham). Ketiga-tiga bentuk ini telah diintegrasikan pemakaiannya oleh masyarakat Melayu (Rahimin Affandi Abd Rahim, 2009).

- Rasionalisme (fahaman bahawa taakulan adalah asas yang paling baik dalam melakukan sesuatu tindakan, menyelesaikan masalah, dan sebagainya) dan empirisisme (doktrin bahawa pengalaman praktis (bukan teori) adalah asas pengetahuan). Hal ini jelas terbukti apabila masyarakat Melayu menekankan kepada pembelajaran dengan alam semesta (ayat kawniyyah) sehingga terhasil teori/hukum alam (konsep adat) yang bersifat kekal (seperti pepatah "biar mati anak jangan mati adat") dan bersifat fleksibel yang perlu berubah mengikut keperluan semasa (seperti pepatah "sekali air bah sekali pasir pantai berubah") (Abdullah Alwi Haji Hassan, 2001: 65-66).

- Bentuk penggunaan akal melalui metafora, alegorikal dan rasional. Ia terdiri daripada aktual (potensi dan fitrah yang dimiliki sejak manusia lahir- bersifat tidak berkembang) dan muktasab (diperolehi dengan cara belajar, membaca, dan mengkaji -bersifat sentiasa berkembang) (Hassan Ahmad, 2004: 1-12).

- Bentuk penelitian sesuatu fenomena kehidupan dan alam secara mendalam. Banyak pepatah Melayu yang menyentuh tentang konsep sains adalah lahir hasil daripada interaksi akal dengan pengalaman hidup dan alam semesta (Ithnin Abdul Jalil. 2001: 452-460). Ia dikaji oleh pemikir Melayu secara mendalam dan berulang kali, yang kemudiannya dinukilkan dalam bentuk pepatah untuk dimanfaatkan oleh anggota masyarakat (Hassan Ahmad, 2004: 1-12). 


\subsection{PERANAN ULAMA DALAM PEMBINAAN TAMADUN TANAH MELAYU}

Dalam bahagian ini, kita akan mendedahkan secara lebih mikro peranan ulama dalam pembinaan tamadun di Tanah Melayu. Tidak keterlaluan jika dikatakan bahawa dalam sejarah Alam Melayu, agama Islam bertindak sebagai kuasa pemangkin utama yang mewujudkan tamadun material dan intelektual yang unggul di rantau Alam Melayu. Teori ini menegaskan bagaimana peranan Islam akan sentiasa dianggap relevan dalam konteks masyarakat Melayu pada setiap zaman, termasuklah dalam konteks zaman moden. Menurut Rahimin Affandi Abd Rahim (2005: 19-51), apa yang lebih penting lagi, fungsi Islam ini dapat dihidupkan dengan usaha yang gigih yang dimainkan oleh ulama Melayu. Jika dirujuk kepada sejarah perkembangan Islam di Alam Melayu, kita boleh menegaskan bahawa ulama Melayu telah mampu untuk bertindak sebagai intelektual ummah dalam beberapa perkara, iaitu;

1. Perancang kepada usaha yang berkesan untuk memperkenalkan agama Islam ke dalam masyarakat Melayu (Abdul Halim el-Muhammady, 1992: 173-184).

2. Pembasmi nilai-nilai feudalisme dan adat pra-Islam yang berakar umbi dalam kehidupan masyarakat melalui institusi pendidikan Islam (Rahimin Affandi Abd Rahim, 2000: 22-25).

3. Penanam benih budaya ilmu ke dalam masyarakat Melayu yang mampu melahirkan sejumlah manusia Melayu yang celik agama serta mampu bertindak mengikut perkiraan ilmunya, menyebarkannya ke dalam masyarakat dan berfungsi sebagai pemimpin masyarakat (Shafie Abu Bakar, 1994: 101-103). Mereka juga telah melahirkan manusia Melayu yang berakhlak tinggi (Abdullah Ishak, 1982: 202-204) dan mampu berdikari tanpa bergantung kepada orang lain. (Ibid: 1982: 202-204).

4. Pemangkin kepada usaha penerapan nilai-nilai Islam ke dalam kebudayaan masyarakat Melayu (Mohd Taib Osman, 1989: 278-280) sehingga Islam kemudiannya menjadi jati diri yang utama kepada kelangsungan diri manusia Melayu (Winstedt, R.O., 1932: 69-90).

5. Penasihat kepada pemerintah Melayu (Mohd. Yusof Iskandar: 52-53) dalam usaha menerapkan nilai-nilai Islam ke dalam sistem undang-undang masyarakat Melayu (Ismail Mat, 1997: 89-90), sehingga melahirkan sejumlah Malay digest Melayu-Islam. (Abdul Rahman Abdullah, 1982: 59-63).

6. Perancang dan pencipta sistem komunikasi dakwah (tulisan jawi) yang berkesan dalam masyarakat yang kemudiannya menjadi bahasa perantaraan (lingua franca) untuk perkembangan ilmiah Islam (Omar Awang, 1981: 80-85) dan hubungan antarabangsa (Mohammad Redzuan Othman, 1994: 53-55).

7. Perancang kepada usaha memperkayakan kesenian (Ahmad Kamal Abdullah, 1988: 47-48; Shafie Abu Bakar, 1987: 95; Mohd Anis Md. Nor, 1990: 30-38) dan kesusasteraan Melayu Islam (Siti Hawa Haji Salleh, 1987:282).

8. Perancang kepada usaha mempereratkan hubungan antara umat Melayu dengan serangkaian umat Islam seluruh dunia (internationalism) di bawah konsep ummah Islam (Nabir Abdullah, 1987: 129-142).

9. Sumber inspirasi kepada usaha menerapkan semangat Perang Salib dalam memerangi kuasa penjajah Barat (Abdul Rahman Abdullah, 1994).

10.Bertindak sebagai benteng terakhir ummah dan pakar rujuk masyarakat yang dilanda krisis kekeliruan akibat daripada penerapan faham sekularisme yang diusahakan oleh penjajah British. (Mohammad Redzuan Othman, 2001: 254-256).

11.Pencetus semangat nasionalisme Melayu yang awal dilihat dari dua aspek (i) usaha menghapuskan kemungkaran dan kezaliman yang berlaku dalam masyarakat Melayu (Abdul Rahman Haji Ismail, 1995: 163-192) dan (ii) usaha membebaskan diri daripada belenggu penjajahan kuasa asing (Mohammad Redzuan Othman, 1998: 154).

12.Perancang utama yang melahirkan golongan literati (pujangga) Melayu pertama yang menanamkan sikap kritikal terhadap proses pemodenan yang dibawa oleh penjajah British. (Mohd. Sarim Mustajab, 1982: 151152). 


\subsection{ALAM MELAYU SEBAGAI KAWASAN ISLAM YANG EKSKLUSIF}

Mohamad Raduan Mohd. Ariff dan Shaharil Talib (1995: 131-146) menyatakan bahawa dalam perkembangan semasa, kawasan rantau Alam Melayu telah dianggap sebagai suatu kawasan penting dan eksklusif dalam kerangka kajian regional studies untuk subjek kawasan masyarakat Islam (Espesito, J., 1996). Ia tergolong sebagai kawasan milik Malaysia dan Indonesia (Shaharil Talib, 1997: 123-135) dan dibezakan dengan kawasan Timur Tengah, Indonesia-Pakistan, Afrika, Eropah dan Amerika Utara. Penetapan kawasan rantau Alam Melayu (Malay Achipelago) yang berbeza dengan kawasan lain dibuat berasaskan kepada pelbagai elemen persamaan yang membabitkan kedua-dua kawasan (Indonesia dan Malaysia) (Riddell, P., 2001).

Persamaan ini antara lainnya merujuk kepada;

1. Kedua-dua lokasi mempunyai perkaitan yang erat dilihat dari sudut sejarah hubungan persaudaraan Melayu yang berasaskan kepada jalinan intelektual keagamaan.

2. Kedua-dua lokasi merupakan kawasan dunia Melayu-Islam terbesar yang mengamal dan memperkembangkan pemikiran Islam menggunakan bahasa pengantar yang sama, iaitu Bahasa Melayu.

3. Persamaan latar belakang sejarah Islamisasi, pengamalan mazhab yang sama dan institusi pengajian keilmuan Islam yang saling mempengaruhi dilihat dari sudut perkembangan tren reformasi pendidikan Islam semasa (Rahimin Affandi Abdul Rahim, 2010: 13-32).

4. Kewujudan jalinan intelektual yang kukuh antara kedua kawasan. Ia merujuk kepada aspek teologi dan syariah yang sama berasaskan kepada mazhab Shafi'i. Ulama daripada kedua-dua kawasan sering bertukar pandangan dan bantuan intelektual sejak dari zaman awal, sekitar tahun 1900an dan semasa era kebangkitan Islam di tahun-tahun 1970-1980an (Rahimin Affandi Abdul Rahim, 2003: 47-74).

Sarjana Barat sering menonjolkan sifat ajaran Islam di Alam Melayu (Malaysia dan Indonesia) sebagai Islam pinggiran yang bukannya murni kerana bercampur dengan pelbagai bentuk khurafat dan bidaah. Hal ini berbeza dengan sifat Islam di Timur Tengah yang dikatakan lebih bersifat sejati dan murni yang perlu dipelajari dan dicontohi secara mutlak. (Azyumardi Azra, 1999: 5-7). Atas dasar ini, kita boleh melihat bagaimana kalangan orientalis barat yang menyusun buku Encylopadia of Islam lebih menumpukan perhatian mereka kepada ulama Timur Tengah dan Indonesia-Pakistan dan bukannya kepada ulama di kawasan pinggiran seperti rantau Alam Melayu. Menurut perkembangan terbaharu, kita dapat melihat hanya satu sahaja buku ensiklopedia, iaitu Encylopadia of Oxford yang turut memberikan tumpuan kepada sumbangan ulama di kawasan Alam Melayu.

Keabsahan teori ini kemudiannya mula dicabar dengan kedatangan era globalisasi yang menyaksikan peta pusat pengajian ilmu-ilmu Islam dunia terbahagi kepada tiga jenis yang utama; (i) dunia Barat yang berteraskan kaedah ala orientalisme (Faisal Ismail, 1997: 35-42) ; (ii) dunia Islam Timur Tengah yang lebih menumpukan kepada kerangka pengajian ala tradisionalisme (Yusri Ihza Mahendra, 1994: 12-19) dan (iii) dunia Alam Melayu (Malaysia dan Indonesia) yang dilihat mengadunkan antara kerangka ala tradisionalisme dan reformisme secara sekaligus (Rahimin Affandi Abdul Rahim, 2005: 105-134).

Walaupun dunia Alam Melayu sering didakwa sebagai pusat pengajian Islam ala peripheral, ternyata pendekatan Alam Melayu (Malaysia dan Indonesia) telah mendapat sambutan dan momentum yang cukup baik, sehingga dikatakan sebagai nisbah utama ajaran Islam ala Nusantara yang bersifat lembut, toleran, dan terbuka dengan perkembangan semasa. (Ibid: xv-xvi).

Sayugia dimaklumkan, pada zaman 1960an IPTA di Indonesia sering dijadikan tumpuan oleh pelajar Islam untuk mendapat pendidikan di peringkat ijazah pertama dan pasca sarjana. Namun begitu, dalam perkembangan semasa, bentuk hubungan antara IPTA Islam Malaysia dan Indonesia telah mula berubah yang dapat dinilai beberapa perkara yang utama;

- Pertambahan jumlah pelajar pasca siswazah Indonesia di IPTA Islam di Malaysia. Jika pada zaman selepas Malaysia merdeka, IPTA Malaysia memerlukan khidmat kalangan sarjana Indonesia bagi membangunkan program pengajian Islam di pelbagai IPTA, hal yang sebaliknya telah berlaku dewasa ini apabila sejumlah pelajar pasca siswazah Indonesia yang datang ke Malaysia bagi mendapatkan khidmat nasihat untuk menamatkan pengajian mereka di peringkat pasca siswazah (Akh. Minhaji, 2003: 62-80). 
- Kelebihan Malaysia dalam membangunkan program keIslaman yang lebih bersifat moderate and praktikal, dirujuk antara lainnya dengan program pembangunan sistem ekonomi Islam, reformasi pendidikan Islam and sebagainya. Lebih penting lagi, sarjana Indonesia sendiri telah mengakui keunggulan peranan Malaysia yang dikaitkan dengan pembangunan idealisme Islam yang berkesan yang ditunjukkan oleh pihak kerajaan sendiri (Ibid, 2003: 62-80).

- Memandangkan beberapa kegkangan sosio-politik, banyak daripada idea canggih yang disuarakan oleh sarjana Indonesia gagal dilaksanakan secara berkesan dalam masyarakat. Atas dasar inilah tidak salah seandainya peranan ini perlu dimainkan oleh kalangan pemikir dan pembuat dasar di Malaysia (H. Faisal Ismail, 2005: 135-138).

- Bahan penerbitan Islam daripada Malaysia kurang diberi peluang untuk berkembang di Indonesia secara luas dan terpaksa berhadapan dengan pelbagai kekangan birokrasi daripada pihak berkuasa Indonesia (Hamedi Mohd Adnan, 2006).

\subsection{SEJARAH HUBUNGAN ULAMA MALAYSIA DAN INDONESIA DI ALAM MELAYU}

Sejak daripada awal pengislaman Alam Melayu, kita dapat menyaksikan bagaimana ulama Tanah Melayu sangat bergantung kepada bantuan ulama Indonesia dalam menanggani isu-isu Islam. Bahkan ia telah sampai kepada satu peringkat bahawa hubungan ini bersifat berat sebelah. Hal ini kemudiannya mula berubah pada zaman moden. Apa yang ingin ditonjolkan ialah hubungan antara ulama dari kedua-dua kawasan ini yang bersifat komplimentari (saling melengkapi) demi kepentingan dakwah Islam. utama, iaitu;

Dalam sejarah hubungan rantau Tanah Melayu dan Indonesia, kita dapat mengesan beberapa perkara

\subsection{TERENGGANU SEBAGAI JAJAHAN TAKLUK EMPAYAR ISLAM DI INDONESIA (KALIMANTAN)}

Mengikut neraca zaman silam, setiap jajahan takluk sesuatu empayar akan menjalankan dasar yang sama dengan pusat empayarnya (Bagoes Wiryomartono, 2012: 115-130). Atas dasar itu apa yang dijalankan oleh empayar pusat di Indonesia akan turut dijalankan oleh jajahan takluknya yang lain (Mohammad Raduan bin Mohd. Ariff, 1997: 138-146), dan dalam konteks ini mendorong pengislaman Terengganu. Maklumat ini boleh didapati daripada penemuan Batu Bersurat di Terengganu. Dalam catatan Batu Bersurat di Terengganu ini kita dapat mengesan beberapa perkara utama;

1) Terengganu adalah jajahan takluk empayar Islam Indonesia apabila gelaran pemerintah, iaitu Mandulika turut dipakai. Gelaran ini adalah merujuk kepada ketua kerajaan di Indonesia yang kemudiannya bertanggungjawab mengislam dan menerapkan hukum Islam di jajahan takluknya di Indonesia dan Terengganu di Tanah Melayu.

2) Fakta bahawa Terengganu sebagai tempat terawal di Tanah Melayu yang menerima dan mengamalkan ajaran Islam secara menyeluruh. Sebelum ini, terdapat teori yang mendakwa Melaka merupakan tempat terawal menerima ajaran Islam di Tanah Melayu, yang dikaitkan juga sebagai pusat yang memperkembangkan Islam ke seluruh jajahan takluk empayar Melaka yang lain. Secara mudahnya, kita dapat mengatakan bukti tempat awal menerima Islam perlu didasarkan kepada wujudnya beberapa artifak yang khusus merangkumi (i) kitab atau manuskrip agama, (ii) masjid tertua, (iii) institusi pendidikan Islam seperti pondok, (iv) kubur seseorang ulama dan (v) yang terpenting sekali pengaruh pemikiran Islam yang berkekalan serta dapat dikesan penggunaannya secara meluas dalam masyarakat. (S. Hossein Nasr, 1990: 13). Seandainya bukti-bukti ini diambilkira, kita akan bersetuju bahawa kawasan pantai timur Tanah Melayu lebih memenuhi syarat bukti tersebut. Hal ini demikian kerana kesemua artifak dan bukti memang terdapat secara lengkap di kawasan pantai timur seperti Terengganu dan Kelantan, dan bukannnya di kawasan pantai barat Tanah Melayu. 
3) Proses penciptaan tulisan Jawi terawal di Alam Melayu. Kita mungkin tidak tahu siapa dan tarikh sebenar tulisan Jawi diperkenalkan dalam konteks Alam Melayu. Namun begitu, mengikut Omar Awang (1981: 80-85), tulisan Jawi yang dikesan dalam Batu Bersurat Terengganu (BBT) merupakan tulisan paling awal dan lengkap. Terpenting sekali, penciptaan dan penggunaan tulisan Jawi dalam masyarakat Melayu telah memperkayakan bahasa Melayu (Amran Kasimin, 1987) dalam bentuk tulisan Jawi yang dijadikan sebagai alat untuk memperkembangkan keilmuan Islam. Sistem pengajian agama dalam bentuk pengajian pondok telah menggunakan bahasa wilayah Timur Laut melalui sistem tulisan Jawi. Fenomena yang mengambilkira elemen tempatan dalam bentuk memilih bahasa tempatan sebagai medium untuk penyebaran ilmu agama telah dilakukan oleh sarjana Islam di kebanyakan dunia Islam seperti penciptaan tulisan Urdu di India dan tulisan Parsi di Iran berdasarkan aspek bentuknya yang mirip kepada bahasa Arab dengan sedikit pengubahsuaian (Omar Awang, 1980: 55).

4) Unsur Islam dapat dikesan dalam BBT, di mana Islam telah memberi nafas sebenar kepada pembinaan world-view (pandangan alam semesta) Melayu. (Abdul Rahman Abdullah, 1999: 50). Hasil penelitian yang dibuat oleh Prof. Hashim Musa mendapati pembinaan tamadun Melayu ini telah diasaskan dengan enam pandangan world-view yang bersumberkan wahyu Allah.Keenam-enam pandangan ini telah menjadi pegangan utama masyarakat Melayu (konsep jati diri Melayu) sehingga pada masa sekarang.Pemilihan Islam sebagai asas jati diri ini ternyata telah menguntungkan masyarakat Melayu kerana seperti yang berlaku kepada masyarakat Arab, Islam juga telah mengangkat martabat tamadun Melayu ke peringkat antarabangsa. (Ibid, 1990: 50). Proses ini antara lainnya telah menimbulkan semangat perpaduan (internationalism) dalam kalangan umat Melayu bahawa kedudukan mereka dalam kerangka Tauhid, ummah dan ukhuwwah bukan terhad kepada lingkungan kawasan dan sejarah Alam Melayu semata-mata bahkan turut membabitkan kesemua umat Islam seluruh dunia dari setiap zaman dengan warisan tamadun yang tinggi (Rahimin Affandi Abdul Rahim, 2000: 18-19).

Menurut Roff, W. (1980: 41), dengan konsep jati diri ini umat Melayu berasa berbangga menganut Islam yang menjadikan mereka sebahagian daripada serangkaian ummah Islam, seperti halnya golongan Arab yang dipandang mulia oleh masyarakat Melayu. Faktor inilah juga yang menyebabkan kerap berlaku dalam sejarah Alam Melayu penentangan terhadap kuasa penjajah Barat yang dianggap sebagai kuasa kafir (Abdul Rahman Abdullah, 1994). Hal ini telah diakui sendiri oleh mubaligh Kristian yang mengatakan bahawa orang Melayu sebagai golongan yang kuat berpegang kepada agama Islam (Tisdall, C., 1916: 348349). Jelasnya, sifat keMelayuan yang begitu sebati dengan Islam telah mengakibatkan sebarang serangan yang dibuat terhadap Islam akan dianggap seperti serangan yang dibuat terhadap asas kebudayaan Melayu (Bird, I., 1967: 20).

5) Dalam BBT tercatat pengisytiharan Islam sebagai agama rasmi di Terengganu yang disertakan dengan pelaksanaan undang-undang Islam oleh Mandulika (gelaran pemerintah Indonesia) bertarikh 22 Februari 1303M. Bagi D.G.E. Hall (1968: 255), proses pendidikan dan perundangan Islam telah bertapak 100 tahun lebih awal. Hanya selepas Islam benar-benar diterima ramai dan menjadi asas kehidupan masyarakat Melayu di Terengganu, barulah ia dicatatkan pada BBT sebagai pengisytiharan dan peringatan tentang kedaulatan Islam di kawasan tersebut. Ada keterangan tentang Allah dan Rasul, di samping bukti bahawa sistem perundangan Islam berupa gabungan antara undang-undang adat dan Islam (Hooker, M.B., 1976: 127-131). Ia membabitkan 9 atau 10 hukum dalam bidang (a) muamalat - tentang hutang-piutang, undangundang keterangan, dan hukuman kerana enggan membayar denda atau melarikan diri daripada hukuman dan (b) hukuman bagi kesalahan zina (Abdul Kadir Muhammad, 1996: 4).

\subsection{HUBUNGAN POLITIK DAN WACANA ILMU ANTARA TANAH MELAYU DAN INDONESIA}

Fakta sejarah mencatatkan bagaimana kedua-dua kawasan mempunyai hubungan keilmuan yang amat erat. Dalam tradisi ilmu Islam, telah wujud pendekatan yang mengakui autoriti dan hierarki ilmu. Andainya terjadi apaapa masalah agama, maka rujukan kepada autoriti atasan akan dibuat. Dalam sejarah kerajaan Melaka ada tercatat kes masalah dalam bidang Usuluddin (persoalan adakah syurga dan neraka telah wujud) yang gagal dijawab telah dirujuk kepada Majlis Ulama di kerajaan Samudra Pasai.

Dalam contoh yang lain, terdapat catatan bagaimana Nuruddin Al-Raniri telah dilantik sebagai penasihat agama tertinggi di kerajaan Samudra Pasai. Beliau turut dilantik atas kapasiti yang sama di kerajaan Pahang apabila 
berkunjung ke negeri tersebut (Abdul Rahman Abdullah, 1990: 127-130). Hal ini menunjukkan bahawa hubungan intelektual dan politik kerajaan Melayu di Alam Melayu memang rapat tanpa memperkirakan semangat kesukuan yang sempit. Hal ini kemudiannya telah berubah dengan datangnya penjajah British dan Belanda yang membawa semangat asabiyah sempit berasaskan kepada konsep Nation State. Jauh sebelum kedatangan kuasa penjajah barat, masyarakat Alam Melayu telah berhubungan dengan cukup damai dan saling melengkapkan antara satu sama lain (Rahimin Affandi Abdul Rahim, 2005: 19-51).

Dalam aspek sosial kemasyarakatan pula, kita boleh mengesan beberapa perkara utama, iaitu;

1. Kerajaan Melayu-Islam di Negeri Sembilan, Selangor dan beberapa daerah lain telah dibangunkan oleh masyarakat Islam daripada Indonesia. Atas dasar ukhuwah Islam masyarakat Tanah Melayu menerima kedatangan saudara mereka daripada Indonesia dengan hati yang terbuka (Meor Ahmad Noor Meor Hamzah, 2001: 66-96).

2. Penduduk asal Acheh bebas berhijrah ke kawasan utara Tanah Melayu sama ada sebagai peniaga, ulama, dan pejuang Islam untuk menentang penjajahan kuasa Barat.

\subsection{JALINAN INTELEKTUAL KAUM MUDA DAN KAUM TUA}

Rekord sejarah Tanah Melayu ada mencatatkan bagaimana ulama daripada kedua-dua aliran reformisme dan tradisionalisme di kedua-dua kawasan memang saling berhubungan untuk memperkukuhkan aliran pemikiran masing-masing. Ulama Indonesia sering dijemput datang ke Tanah Melayu untuk berhujah dan mengeluarkan pandangan dalam isu pertentangan ini. Majalah dan bahan buku daripada Indonesia juga tersebar meluas di Tanah Melayu (Ibrahim Abu Bakar, 1994: 165-166).

Pertentangan Kaum Muda-Tua ini memperlihatkan bagaimana;

1. Ulama proaktif dengan perkembangan zaman mereka, dan bukannya menjadi penyaksi peristiwa sejarah semata-mata tetapi turut berusaha menangani isu tersebut dengan proaktif.

2. Pertentangan kaum muda-tua ini berlaku kerana faktor perbezaan falsafah, aliran, dan paradigma menggunakan Islam untukmenghadapi keperluan zaman. Hal ini kemudiannya tidak mati begitu sahaja bahkan masih diteruskan hingga kini. Banyak idealisme dipegang oleh kedua-dua aliran tersebut masih lagi kekal hingga zaman moden. Beberapa contoh boleh diberikan, antaranya;

a) Banyak sekolah dan madrasah daripada aliran reformisme tumbuh dengan begitu pesat sekali. Aliran ini telah mendapat momentumnya di Malaysia apabila aliran reformisme (asalnya daripada aliran kaum Muda) diterima secara meluas oleh IPT di Malaysia. Manakala fahaman tradisionalisme (asalnya aliran kaum Tua) tetap kekal di Malaysia dan Indonesia yang bertumpu di pondok-pesantren tradisional. (Rahimin Affandi Abdul Rahim, 2000: 2143).

b) Agensi agama Islam di Malaysia tetap kuat berpegang kepada aliran tradisional kerana mereka telah membentuk status quo yang tersendiri (Rahimin Affandi Abdul Rahim, 2008).

Pada penghujung tahun 1930-an, isu pertentangan kaum muda-kaum tua telah mula beransur hilang disebabkan oleh beberapa faktor semasa yang timbul di kalangan masyarakat Melayu seperti dominasi golongan nasionalis Melayu memperjuangkan kemerdekaan Tanah Melayu (Mohd. Sarim Mustajab, t.t: 150). Keadaan ini telah mendorong sesetengah sarjana mengatakan bahawa kaum muda telah gagal dalam usaha mereka menjalankan usaha tajdid di Tanah Melayu (Ibrahim Abu Bakar, t.t.: 171-172). Kenyataan ini sebenarnya tidak berasas kerana usaha tajdid kaum muda dalam konteks sejarah Malaysia telah meninggalkan banyak kesan jangka panjang dan juga kesan jangka pendek.

Dilihat dari kesan jangka pendek, kaum muda telah melahirkan golongan intelektual Melayu yang dapat menganalisis perkembangan baru yang timbul dalam masyarakat Melayu kesan daripada dasar pemodenan kuasa British. Kesedaran ini kemudiannya telah mencetuskan kesedaran politik (nasionalisme) orang Melayu yang melahirkan beberapa pertubuhan politik berteraskan Islam dan Melayu seperti HAMIM, PAS, dan KMMM. 
Pertubuhan-pertubuhan ini kemudiannya menyebarkan beberapa intipati utama gerakan tajdid kaum muda seperti penekanan kepada kepentingan akal dan logik, tauhid, kepentingan pendidikan moden, pembangunan ekonomi bangsa Melayu, demokrasi dan perpaduan umat Islam sejagat (Mohd. Sarim Mustajab, t.t.: 151-152).

\subsection{JALINAN DAKWAH DAN INTELEKTUAL PADA ZAMAN KEBANGKITAN SEMULA ISLAM (TAHUN-TAHUN 1970AN-1990AN)}

Pada akhir dekad 70an dan permulaan dekad 80an, seperti masyarakat Islam luar, keadaan di Malaysia juga telah dilanda dengan gelombang kebangkitan semula Islam. Arus ini ditandai dengan munculnya kesedaran untuk menyerap dan menegakkan nilai-nilai dan etika Islam dalam seluruh kehidupan (Husin Mutalib, 1990: 127-147) yang diperjuangkan oleh sejumlah besar pertubuhan Islam seperti ABIM, PAS, Tabligh, Arqam, PERKIM, USIA dan sebagainya.

Hasrat dan keinginan kepada penghayatan Islam kemudiannya telah turut diterima oleh pihak kerajaan sendiri. Dua contoh utama boleh diberikan dalam soal ini. Pertama, asas dan kaedah gerakan reformasi yang digambarkan oleh Walid Saif (1995: 59-60) sebagai "The reformist moderate model which advocates the use of peaceful means to produce desirable changes. The stress here is on evolution rather than revolution. One of the basic common ideas in this context is to build up general awareness and opinion and to create a wide public base through education, guidance, the establishment of effective Islamically oriented service and public institutions" telah diterima pakai oleh pihak kerajaan, memandangkan ia secara langsung tidak mencabar kewujudan dan keabsahan pihak kerajaan. Sebaliknya, mengikut kaca mata pihak kerajaan, dasar dan prinsip golongan reformasi ini sekiranya dilaksanakan akan menghasilkan suatu dasar yang cukup baik dan teratur. Apa yang lebih penting lagi ia dapat memberi peluang kepada pihak kerajaan untuk mengelola dan mengawasi gerakan golongan reformasi (Roof, W., 1988: 221-222).

Contoh kedua ialah gagasan anti sekularisme yang diperjuangkan oleh badan dakwah dan sarjana tempatan telah diterima baik oleh pihak kerajaan (selain daripada faktor untuk menolak populariti parti pembangkang) yang kemudiannya mencetuskan dasar Islamisasi (Ibid, 1995:151-156). Menurut Prof. Muhammad Kamal Hassan (1996: 107-110), dasar ini pada asasnya dibuat berdasarkan beberapa prinsip utama, iaitu;

a) Proses meletakkan Islam sebagai al-din (way of life) seperti yang pernah dilakukan pada zaman sebelum kedatangan kuasa British. Ia juga disifatkan sebagai proses membebaskan diri daripada warisan peninggalan penjajah.

b) Proses mengubah fahaman sekularisme (desecularization) yang telah menyerap masuk ke dalam seluruh kegiatan kehidupan dan jentera pentadbiran di negara Malaysia yang merdeka.

c) Proses memperbetulkan perancangan dan pelaksanaan kebanyakan dasar pembangunan negara yang sebelumnya telah dipengaruhi sepenuhnya dengan fahaman sekularisme.

Pada zaman ini, seperti zaman sebelumnya, perkaitan dan jalinan dakwah serta intelektualisme antara Malaysia dan Indonesia masih lagi wujud berasaskan semangat ukhuwwah seperti yang terjalin sebelumnya. Antara jalinan yang dimaksudkan merangkumi;

1) Penyatuan idea dan kerjasama membabitkan gerakan Islam di Malaysia dan Indonesia. Hal ini boleh dilihat dari pendekatan aspek latihan dakwah antara gerakan Islam di kedua-dua kawasan dan penggunaan pendapat para sarjana Islam Indonesia oleh gerakan Islam di Malaysia dalam menangani kebanyakan isu-isu yang timbul di Malaysia. Untuk memperjelaskan lagi kenyataan ini kita boleh mengemukakan beberapa perkara penting, seperti:-

a) ABIM mempunyai hubungan yang rapat dengan Himpunan Mahasiswa Islam (HMI) (Tanja, V., 1982), yang dilaporkan telah turut serta menghadiri Seminar Pengkaderan anjuran HMI pada tahun 1970 yang diadakan di Pekalongan, Indonesia. Sejak itu, kebanyakan formula latihan kepimpinan dan dakwah yang diamalkan oleh HMI telah turut diterimapakai oleh ABIM. Begitu juga ABIM telah menyanjung tinggi pendapat dan pandangan yang diberikan oleh tokoh-tokoh HMI seperti Dr. Deliar Noer, M. Imaduddin Abdul Rahim, dan Azyumardi Azra. 
b) Pendekatan perjuangan yang berbentuk reformisme yang disertakan dengan perancangan blueprint yang lengkap mengantikan pendekatan secara retorik semata-mata yang diamalkan oleh Muhamadiyyah (Nasir Tamara, 2000: 367-372) telah ditiru oleh kebanyakan gerakan Islam di Malaysia dengan menubuhkan beberapa program dan institusi seperti KOHILAL, KBI, Sekolah al-Amin, TASKA, TASKI dan sebagainya, sebagai usaha menangani persoalan yang timbul dalam masyarakat (Husin Mutalib, t.t.: 136138).

c) ABIM dengan kerjasama Dewan Bahasa dan Pustaka (DBP) telah menganjurkan seminar tentang Hamka dan transformasi sosial di Alam Melayu yang mengkhususkan sumbangan Hamka selaku sasterawan, sejarawan, pemikir sosial, ahli tafsir dan novelis yang amat berpengaruh di Malaysia. Seminar ini sekali lagi telah menonjolkan sumbangan Hamka selaku intelektual ummah seperti tokoh-tokoh lain yang memang begitu terkenal di rantau Alam Melayu (Riddel, P., 2001; Hashim Musa, 2001).

2) Pandangan daripada karya intelektual sarjana Indonesia telah mendapat sambutan yang baik daripada kalangan sarjana Malaysia. Apa yang jelasnya, berbanding dengan realiti Malaysia, suasana budaya ilmu di Indonesia adalah lebih pesat dan begitu prolifik. Hal ini terbukti dengan wujudnya kesungguhan usaha penterjemahan karya ilmiah Islam dan penghasilan karya ilmiah yang lebih asli dalam kalangan sarjana Indonesia. Rataratanya buku-buku ilmiah dari Indonesia ini, sama ada dalam bentuk terjemahan dan karya asli telah membanjiri kebanyakan kedai buku terkenal di Malaysia yang memungkinkan pengaliran pengaruh intelektual ala Indonesia ini memasuki alam ilmiah Malaysia.

\subsection{JALINAN SARJANA KEDUA-DUA KAWASAN DALAM WACANA ISLAMISASI ILMU}

Gagasan Islamisasi ilmu ini antara lainnya mempunyai beberapa intipati utama;

Pertama, ilmu yang dipakai dalam konteks dunia semasa yang rata-ratanya dipegang oleh masyarakat dunia adalah hasil pemakaian world-view dan sistem epistemologi sekularisme barat yang memang bertentangan dengan prinsip Islam dan wajib ditentang oleh umat Islam.

Kedua, ilmu Barat dalam semua disiplin penuh dengan keburukan yang memberi kesan yang merosakkan sistem ekologi dan merosak jiwa manusia. Ia akan membawa lebih banyak masalah kepada umat manusia. Worldview sekularisme Barat menolak agama sebagai neraca ilmu dan kebenaran dalam kehidupan manusia, sebaliknya agama dikatakan sebagai punca penderitaan umat manusia (Idris Zakaria, 1999: 15-21). Sebagai gantinya, manusia moden yang inginkan kemajuan perlu bergantung sepenuhnya kepada akal semata-mata.

Dalam konteks penguasaan ilmu pengetahuan, pergantungan kepada akal manusia telah ditumpukan kepada dua aspek yang utama, (i) memahami hakikat, kebenaran, dan matlamat hidup manusia dan (ii) mempergunakan akal tanpa bimbingan wahyu untuk tujuan pengurusan dan pembangunan hidup manusia. Dalam aspek yang berikut (i), perbincangan tentang elemen epistemologi (isu sumber, status, dan neraca penilaian sesuatu ilmu) telah melahirkan dua aliran, rasionalisme (akal sebagai sumber utama ilmu) dan aliran empirisme (pengalaman sebagai sumber ilmu dan kebenaran). Kedua-dua aliran ini pada dasarnya menolak semua elemen ketuhanan dalam kehidupan manusia. Begitu juga dalam aspek (ii), proses pengurusan dan pembangunan hidup manusia lebih bertumpu kepada matlamat memberikan kepuasan kebendaan dan nafsu manusia.

Asas world-view sekularisme ini kemudiannya melahirkan falsafah humanisme (Mohd Kamal Hassan, 1996) yang menumpukan semua urusan pembangunan kehidupan dunia tanpa pertimbangan akhirat malah semata-mata untuk kepuasan diri dan nafsu manusia. Falsafah ini kemudiannya telah melahirkan sejumlah besar paradigma disiplin keilmuan bagi tujuan pengurusan dan pembangunan tamadun materialistik. Ia terdiri daripada;

Pertama, paradigma logikal empirikal positivisme - bagi setiap kajian keilmuan dan dianggap sebagai satusatunya cara untuk mendapatkan ilmu yang paling tepat dan betul, yang kononnya dibuat melalui kaedah yang cukup sistematik, teliti, dan objektif (Mohd Natsir Mahmud, 1997: 10-12). Manakala pengkajian yang berpandukan sumber wahyu akan dianggap sebagai tidak saintifik dan tidak boleh dibuktikan secara empirikal (semua perkara yang boleh ditangani secara lahiriah dengan pancaindera) (Abdul Rahman Abdullah, 2000: 71-72). Pendekatan ini pada dasarnya berpunca daripada sikap mereka yang menolak agama dan perkara-perkara ghaib yang tidak dapat dilihat dan ditangani dengan pancaindera (Safi, L., 1998: 190-1999). 
Kedua, pemakaian paradigma Materialistik-Mekanisme perlu dipakai sepenuhnya dalam proses membangunkan aspek fizikal yang membabitkan alam sekitar dalam sebuah masyarakat. Paradigma ini menganggap alam sebagai sumber utama yang berupa material-mekanis semata-mata dan tidak mempunyai nilai spiritual (nyawa) yang perlu bergantung kepada kuasa ketuhanan. Pandangan ini telah melahirkan sifat sekularis dan individualistik yang lebih menjurus kepada mementingkan kebajikan manusia berbanding dengan kebajikan alam. Hasilnya, berasaskan kepada paradigma ini, dua penekanan telah diberikan; (i) Alam dan segala isinya dianggap sebagai sumber utama yang bakal menambahkan kekayaan manusia sekularis- yang perlu diperah hasilnya semaksimum mungkin dan (ii) Alam perlu diteroka dan dikaji mengikut kerangka pemahaman saintifik materalisme-sekularisme agar segala hukumnya yang bersifat praktikal boleh dikaji demi untuk kepentingan manusia moden.

Intipati ketiga gagasan Islamisasi ilmu menetapkan bahawa sebelum ilmu Barat dapat diterima ia perlu ditapis dan disaring menggunakan sistem epistemologi Islam yang agak ketat. Mengikut Syed Muhammad Naquib alAttas, proses tapisan ini perlu mengambilkira world-view, ontologi, epistemologi, dan aksiologi yang terkandung dalam ilmu Barat. Lebih lanjut lagi, proses tapisan ini memerlukan beberapa langkah utama (Zaini Ujang, 1989: 3942);

1) Menguasai disiplin ilmu moden (Barat).

2) Kajian mendalam terhadap sesuatu disiplin Barat.

3) Menguasai warisan ilmu Islam.

4) Analisis warisan ilmu Islam.

5) Mengemukakan kaitan Islam dengan sesuatu disiplin moden.

6) Penilaian terhadap disiplin ilmu moden.

7) Penilaian terhadap warisan ilmu Islam.

8) Kajian terhadap masalah ummah.

9) Kajian terhadap masalah manusia sejagat.

10) Analisis dan sintesis terhadap kedua-dua disiplin moden dan Islam.

11) Penulisan buku teks yang mengandungi disiplin ilmu.

12) Menyebarluaskan ilmu yang telah diislamkan.

Mengikut pengamatan semasa, kita dapat mengesan beberapa perkara yang membabitkan gagasan Islamisasi ilmu di Malaysia dan Indonesia. Kesemuanya secara jelas memperlihatkan bahawa gagasan ini bukan setakat menjadi bahan wacana semata-mata, bahkan turut dilaksanakan intipatinya dalam kehidupan;

Pertama, persetujuan terhadap keburukan proses sekularisasi yang dibawa oleh penjajahan kuasa Barat. Kesemua sarjana Islam di kedua-dua kawasan bersetuju bahawa proses penjajahan kuasa Barat (British dan Belanda) telah menyebabkan berlakunya proses sekularisasi dalam semua aspek kehidupan masyarakat Islam. Lebih penting lagi, fahaman ini telah meresap dalam pemikiran masyarakat Islam. Ia terdiri daripada;

a) Pengosongan alam tabii dan akal insani daripada unsur ketuhanan - manusia bebas melakukan sesuatu program pembangunan tanpa mempedulikan kuasa Tuhan.

b) Penafian terhadap kekuasaan politik yang berdasarkan sumber agama.

c) Pengenalan sistem penilaian nisbi/relatif terhadap agama; manusia bebas tentukan masa depannya sendiri.

d) Penurunan taraf ilmu agama, berbanding dengan ilmu bukan agama - tumpuan lebih diberi kepada ilmu bukan agama yang kononnya boleh membawa kemajuan (Mohd Hazim Shah Abdul Murad, 2005: 91-92).

e) Penakrifan konsep kebenaran (truth) yang keliru dan mengikut paradigma sekularisme. 
Kedua, penubuhan NGO/LSM khusus yang memperjuangkan gagasan Islamisasi ilmu. Dewasa ini, perjuangan menegakkan usaha pelestarian Islam dalam masyarakat dikatakan boleh dibuat melalui beberapa cara; terlibat dalam sistem pemerintahan, pendidikan dan NGO. Sarjana Islam di kedua-dua kawasan rata-ratanya bersepakat bahawa peranan NGO Islam amat diperlukan bagi memperjuangkan sesuatu gagasan tertentu. Bahkan dalam ketiga-tiga aspek yang dinyatakan sebelumnya ia bersifat komplimentari atau saling melengkapi antara satu sama lain bagi melestarikan Islam dalam masyarakat Islam.

Peranan NGO ini yang ditubuhkan atas tujuan tertentu dan dianggotai oleh sejumlah besar pakar ilmu (Intellectual Circle) memang mempunyai sejarah yang panjang dalam memperkembangkan keilmuan Islam dalam pelbagai falsafah yang tersendiri. Pada zaman klasik, walaupun ia bukan NGO tetapi intipati utama perjuangan Intellectual Circle memang menyamai konsep NGO masa kini.

Di Malaysia, gagasan Islamisasi ilmu telah melahirkan beberapa NGO khusus. Selepas Malaysia mencapai kemerdekaan dan tersebarnya gelombang kebangkitan semula Islam pada tahun-tahun 1970-2000an, telah muncul Intellectual Circle saintis Melayu-Islam yang bernaung di bawah ASASI. Kebanyakan mereka terdiri daripada kakitangan akademik Melayu yang mendapat didikan daripada universiti di Barat, tetapi kuat terpengaruh dengan idealisme Islam (Mohamad Abu Bakar, 2001: 407-410).

Kita boleh mengenal pasti beberapa peranan Akademi Sains Islam (ASASI) dalam memperjuangkan konsep sains Islam. Antaranya;

1) Kritikan dibuat terhadap konsep sains Barat. Butiran kritikan ini merangkumi;

a) Masyarakat Melayu seolah-olah tertipu apabila menganggap sains Barat berfahaman sekular yang berasaskan logico positivisme sebagai paling benar dan universal penggunaannya. Sedangkan konsep sains Barat ini sebenarnya dikritik hebat oleh golongan saintis Barat di Eropah sendiri (Mohd Hazim Shah Abdul Murad, 2005: 91-94).

b) Sains Barat yang diagung-agungkan sebenarnya adalah sains yang paling muda usianya berbanding dengan ilmu sains yang berteraskan ciri tempatan dan ada hubungan dengan tuhan. (Abdul Rahman Abdullah, 2010). Di Alam Melayu sendiri sebelum kedatangan penjajah Barat telahpun ada warisan sains Melayu yang agak cemerlang (seperti meriam Melayu yang dilaporkan lebih hebat daripada meriam Portugis, kapal Melayu yang lebih kukuh daripada kapal Eropah). Memang ada manuskrip Melayu yang mengandungi semua maklumat sains Melayu ini. (Shaharir Mohamad Zin, 2003: 157-203).

2) Intellectual circle Melayu semasa seperti GAPENA dan ASASI secara kuat memperjuangkan kemampuan bahasa Melayu digunakan sebagai bahasa ilmu untuk pengembangan ilmu sains. Mereka secara terangterangan mencabar dakwaan bahawa Bahasa Melayu tidak mampu digunakan untuk membangunkan pengetahuan bertaraf tinggi seperti konsep sains Islam.

3) ASASI memperjuangkan gagasan Pemeribumian Sains Melayu-Islam. Mengikut Osman Bakar (1989: 10), status negara Malaysia yang maju hanya akan dapat dicapai apabila masyarakat Melayu membangunkan kaedah sainsnya sendiri, yang mana sains Barat diterima dan ditapis secara selektif dengan sains MelayuIslam. Dengan cara ini, masyarakat Melayu bukan sahaja akan mempunyai kekuatan dari segi peralatan, bahkan juga pemikiran. Sebelum kedatangan kuasa penjajah, masyarakat Melayu telah mempunyai pengetahuan dari segi sains dan teknologi. Antaranya dalam bidang astronomi, astrologi, kosmogeni, matematik, perubatan, fizik, dan sains hayat.

Di Indonesia pula, pelbagai NGO Islam muncul seperti INSIST yang membawa usaha penentangan terhadap fahaman liberalism Barat yang mempengaruhi ajaran Islam. Ia lebih berbentuk serangan balas terhadap usaha yang dijalankan oleh golongan Islam Liberal. Mengikut pandangan INSIST, konsep kelimuan Barat tidak harus diterima begitu sahaja, tetapi perlu dilihat kepada world-view yang mendasari keilmuan tersebut.

World-view adalah pandangan manusia tentang diri, alam, dan kehidupan. Ia ditentukan oleh agama, budaya, falsafah, dan perkembangan sains dan teknologi, yang secara langsung mempengaruhi sikap dan tindakan seseorang. Mengikut Hamid Zarkashi (2004: 1-6), world-view Islam adalah visi tentang realiti dan kebenaran, berupa kesatuan pemikiran yang arsitektonik, yang berperanan sebagai asas yang tidak nampak (non-observable) bagi semua perilaku manusia, termasuk aktiviti ilmiah dan teknologi. Antara elemen asas untuk world-view Islam terdiri 
daripada konsep tuhan, wahyu, dan penciptaannya, psikologi manusia, ilmu, agama, kebebasan, nilai, serta kebajikan dan kebahagiaan yang dalam tulisannya menyatakan bahawa elemen-elemen inilah yang kemudiannya yang menentukan bentuk perubahan (change), perkembangan (development) dan kemajuan (progress) dalam Islam. Atas dasar ini, ternyata keilmuan Barat moden memang memiliki elemen fahaman sekularisme yang harus ditentang oleh umat Islam.

Apa yang diperjuangkan oleh INSIST ini ternyata bertepatan dengan realiti wujudnya penganut aliran Liberalisme yang berpegang dengan paradigma taksub melulu dengan semua elemen daripada Barat yang dianggap sesuai dengan konteks zaman moden. Lebih penting lagi, kumpulan Islam Liberal ini telah menimbulkan pelbagai isu Liberalisme yang merangkumi isu penindasan wanita, ketertutupan Islam dengan perkembangan moden dan sikap anti terhadap golongan bukan Islam (Abd Moqsith Ghazali, 2007: 412-431). Contohnya, Luthfi Assyaukani (2007: 241-244) menegaskan bahawa sekularisme tidak bercanggah dengan Islam, malah ia memberi berkat kepada Islam dan agama-agama lain. Menurutnya lagi sebuah demokrasi yang baik hanya boleh dilaksanakan jika ia mampu menerapkan prinsip-prinsip sekularisasi yang benar. Amerika Syarikat, Australia, dan negara-negara lain tidak menganggap sekularisme sebagai musuh agama, bahkan pelindung agama. Penerapan sebeginilah yang disarankan oleh Luthfi Assyaukanie untuk mendapat berkat sekularisme.

Ketiga, penerapan gagasan Islamisasi ilmu dalam sistem pendidikan tinggi Islam.

Di Malaysia, gagasan Islamisasi ilmu telah dijadikan falsafah dan asas utama penubuhan UIAM, USIM dan kemudiannya diterap sama oleh beberapa IPT yang menawarkan disiplin pengajian Islam. Di Indonesia, beberapa UIN juga dilihat berusaha menerapkan falsafah Islamisasi ini dengan menggunapakai pelbagai teori pendidikan yang berbeza, walaupun falsafahnya tetap sama; mengakui kelemahan sistem pendidikan Islam dan keperluan melakukan Islamisasi ilmu. Ia dikesan membawa Teori Integrasi Ilmu Agama Dan Umum, Teori Peta Labah-Labah, Teori Jaringan Roda dan Teori Menara Berkembar. Terpenting sekali, kita mendapati sarjana Malaysia kurang memberikan penekanan kepada aspek falsafah yang bersifat abstrak, tetapi lebih suka menerapkan aplikasi Islamisasi ilmu dalam kurikulum di IPTA. Hal ini berbeza dengan realiti di Indonesia yang mana mereka lebih suka menumpukan perhatian kepada konsep dan falsafah Islamisasi ilmu, yang sayangnya soal aplikasi kurang diberikan penekanan.

\subsection{PENERUSAN WACANA IDEALISME ISLAM YANG ANTI EKSTRIMISME}

Ia membabitkan penentangan terhadap pendekatan ekstrimisme dalam pemahaman agama Islam. Sarjana dari kedua-dua kawasan bersepakat bahawa sebarang bentuk perjuangan yang menggunakan kaedah ekstrimisme perlu ditentang kerana ia bakal merosakkan citra Islam itu sendiri. Walaupun apapun nama dan tren perjuangan, mereka sepakat menolak elemen kekerasan yang melampau yang boleh diperincikan sebagai; (Hashim Musa, 2004: 232);

1) Ekstrimisme; melampaui batas dan keseimbangan apabila mentafsir dan melaksanakan sesuatu peraturan ataupun hukum secara ekstrim.

2) Chauvisnisme; taksub apabila menganggap fikiran atau kumpulan sendiri adalah yang terbaik, manakala fikiran atau kumpulan lain tidak benar dan mesti ditolak.

3) Fanatisisme; tindakan membuta tuli (menghampiri psikosis) dalam mengikuti dan melaksanakan sesuatu cara, pendapat dan pendekatan sendiri tanpa mempedulikan bahkan menolak sekeras-kerasnya pendapat orang lain.

Memang terdapat serangkaian aktiviti dan pegangan melampau yang dijalankan oleh penganut Islam semasa, sama ada di Malaysia (Mohd Mizan Aslam, 2009: 145-157) ataupun Indonesia (Amir Santoso, 2007: 323-338; Haedar Nashir, 2007: 167-168), antaranya;

1) Amalan melampau telah menyebabkan berlakunya perpecahan dan pertumpahan darah sesama umat Islam yang cukup dahsyat sekali. Contohnya boleh dilihat daripada peritiswa kematian Imam Shafi'i yang dipukul oleh penganut fanatik mazhab Maliki akibat perbezaan pendapat antara mazhab Maliki dan mazhab Syafii dalam satu isu furu'iyyah yang kecil sahaja. Begitu juga halnya dengan pergaduhan antara pengikut mazhab Sunni dan Syiah dalam isu-isu biasa yang sepatutnya boleh diselesaikan melalui perbincangan ilmiah. 
2) Kes Pengeboman Bali. Dalam perbicaraan kes tersebut yang dibuat di mahkamah Indonesia yang turut dihadiri oleh keluarga mangsa, tertuduh utama yang bernama Amrozi telah tersenyum sinis dan mengatakan perkataan "go to hell with you infidel" kepada semua keluarga mangsa korban yang berada di dalam mahkamah tersebut. Pihak media Barat yang turut serta membuat liputan di dalam perbicaraan tersebut telah mengambil kesempatan menjadikannya sebagai isu utama yang menonjolkan bahawa Islam memang mengajar penganutnya bersikap zalim dan biadap terhadap golongan bukan Islam.

3) Peristiwa 11 September yang memusnahkan WTC dan Pentagon telah menyebabkan kuasa Barat yang dipimpin oleh Amerika Syarikat melakukan pencerobohan terhadap dua negara umat Islam, iaitu Aghanistan dan Iraq.

4) Pengaruh global Salafi melampau yang didasarkan kepada mentaliti Perang Salib dan Neo-kolonialisme Barat, khususnya terhadap kuasa Barat dan Zionisme, yang mewajibkan penggunaan kaedah kekerasan untuk menanganinya. Lebih buruk lagi, hal ini turut diperpanjangkan dengan faktor perbezaan mazhab dalam Islam, seperti kes perbezaan antara dua mazhab terbesar dalam Islam, Sunni dan Syiah - Kes Kumpulan al-Qaeda di bawah pimpinan Abu Mus'ab al-Zarkawi di Iraq.

5) Pembentukan sebuah pemerintahan Islam bukan sekadar suatu alternatif, tetapi suatu kewajiban Syar'i berdasarkan perintah dan kehendak Allah. Hal ini demikian kerana setiap penganut Islam harus patuh dengan mematuhi kehendak Allah, khususnya dalam bidang pemerintahan. - Kes pemerintahan Taliban di Aghanistan.

6) Memandangkan legitimasi pemerintah Islam didasarkan kepada syariah Allah, maka pemerintah yang tidak mematuhi syariah adalah tidak sah. Mana-mana pemerintah dan individu Islam yang tidak mematuhi syariah Allah akan dianggap bersalah dan kafir yang wajib diperangi menggunakan konsep Jihad - Kes pembunuhan Anwar Sadat oleh pengikut kumpulan Takfir wa'l-Hijrah.

7) Program penentangan terhadap pemerintah Islam yang ingkar perlu diperluaskan untuk memerangi ulama rasmi berserta dengan semua prasarananya (seperti masjid dan sekolah) yang dilihat bergabung dengan pihak pemerintah - Kes Jemaah Islamiyyah dan Front Pembela Islam di Indonesia.

8) Jihad melawan kekafiran dan golongan yang bersimpati dengannya adalah dianggap sebagai tugas suci. Oleh itu, memerangi golongan ini diwajibkan ke atas semua mukmin sejati, yang perlu juga diperluaskan kepada semua golongan awam dan kepentingan mereka. Seperti golongan Khawarij yang menuntut komitmen kesetiaan dan ketaatan yang total. Bagi mereka, seseorang itu dilihat dari segi status keagamaannya, yang hanya berada dalam dua keadaan semata-mata; sama ada Islam ataupun kafir.

9) Golongan Kristian dan Yahudi dianggap sebagai kafir, dan bukannya sebagai Ahli Kitab kerana hubungan mereka dengan kuasa kolonialisme Barat dan Zionisme. Mereka dipandang sebagai rakan rapat dalam sebuah konspirasi Yahudi-Kristian melawan Islam dan dunia Islam.

10) Generasi muda Islam digalakkan untuk terlibat dalam memerangi golongan kafir sebagai anti tesis kepada golongan Islam, yang dikatakan bakal memperoleh status mati syahid seandainya sanggup mengorbankan dirinya dalam pengeboman secara berani mati.

Bersamaan dengan pendekatan ini, sarjana Islam dari kedua-dua kawasan memperjuangkan agar umat Islam mengamalkan sikap selektif dengan keilmuan Barat (Lili Yulyadi Amakim \& Ibnu Hamad, 2010: 3-10). Kita sering terperangkap dengan sikap melampau yang menolak kesemua perkara yang datang daripada Barat. Dalam soal keilmuan ini, sarjana dari kedua-dua kawasan mengakui memang terdapat beberapa elemen positif yang dimiliki oleh masyarakat Barat, khususnya yang membabitkan dunia ilmu. Bagi elemen yang positif pula, kita dapat mengesan beberapa perkara yang boleh dijadikan input berguna untuk proses berfikir bagi umat Islam. Ia terdiri daripada (Abdul Rahman Embong, 2003);

1) Teori dan formula pembangunan Barat adalah cukup dinamik dan sentiasa berubah.

2) Realiti masyarakat dan kepimpinan politik Barat lebih telus dan demokratik (civil society).

3) Barat sentiasa melakukan proses semakan (reviewing) terhadap semua konsep dan paradigma silam yang diikuti dengan usaha penambahbaikan yang sepatutnya. Hal ini boleh dilihat daripada usaha sarjana dan 
masyarakat mengkritik kelemahan paradigma sekularisme silam - terbukti apabila mereka lebih mengamalkan sikap positif dengan keperluan agama dalam hidup. Ia turut disertakan dengan usaha menitikberatkan soal penjagaan sistem ekologi dunia.

4) Realiti kepimpinan politik Barat yang lebih suka berpegang kepada hasil research and development (R\&D) yang dijalankan oleh para ilmuwan.

5) Tahap kemajuan ekonomi masyarakat Barat yang lebih maju, khususnya membabitkan penguasaan mereka terhadap seluruh sistem di dunia, antara lainnya kerana dunia Barat memiliki kecanggihan ilmu pengetahuan dan seterusnya mampu mendominasi semua elemen kehidupan dunia moden (Hashim Musa, 2004: 191-192). Dalam soal ini, Hashim Musa menegaskan bahawa Amerika Syarikat sebagai tamadun teras Barat kini mendahului negara-negara lain di dunia dalam pelbagai bidang kira-kira 20 tahun ke hadapan, seperti;

- Mendahului bidang teknologi.

- Memiliki sifat keusahawanan yang tinggi.

- Setiap lapisan rakyatnya digalakkan membuat eksperimen dan inovasi yang bermula daripada kosong. Contohnya, apa yang dijalankan oleh Microsoft dan Dell Computers.

- Membenarkan tenaga muda dalam organisasi bersuara dan memimpin jika berupaya.

- Berjaya memupuk dan memanfaatkan akal fikiran tenaga muda yang aktif dan produktif untuk kemajuan organisasi dan komuniti.

6) Konsep modal insan Barat menitikberatkan beberapa sifat yang amat diperlukan untuk kerjaya moden, merangkumi; (H. Syahrin Harahap, 1999: 11-25)

- Menunda kesenangan jangka pendek untuk kesenangan jangka panjang.

- Memanfaatkan waktu dan etos kerja yang cemerlang.

- Yakin dengan keadilan dapat disebarkan kepada manusia.

- Menekankan pengamalan budaya ilmu sebagai kaedah untuk melahirkan kreativiti akal yang tinggi.

- Menyanjung tinggi bakat dan kemampuan serta penghargaan diberikan berdasarkan prestasi dan bukannya berasaskan kepada paradigma feudalisme.

\subsection{KESIMPULAN}

Sebagai rumusan akhir, kita boleh menegaskan bahawa terdapat beberapa intipati penting berkaitan dengan pendekatan dakwah serantau, jika dirujuk kepada perkembangan sejarah yang pernah berlaku di rantau Alam Melayu. Pertama, walaupun kita sering berbangga dengan perkembangan hidup yang lebih baik pada zaman moden ini dan sering memandang rendah terhadap zaman silam, tetapi dilihat dari segi dinamika perkembangan Islam pada zaman silam, ternyata ia lebih baik berbanding dengan zaman moden. Kedua, walaupun konsep dan tema dakwah serantau telah diperkenalkan pada zaman moden ini, ia sebenarnya dipandang dari sudut teori dan praktikal telah diamalkan secara menyeluruh sejak dahulu oleh penganut Islam di Alam Melayu. Ketiga, peranan yang cukup proaktif ke arah melahirkan intelektual ummah yang terdiri daripada ulama terbilang yang sanggup berkorban demi menegakkan kalimah Allah di rantau Alam Melayu telah berjaya dimainkan oleh institusi pendidikan Islam silam. Akhir sekali, kita boleh melihat aura kehebatan jalinan dakwah dan intelektual silam masih lagi diteruskan sehingga pada masa sekarang yang membabitkan usaha dan kerjasama para alim ulama dari Alam Melayu.

\section{Rujukan}

(1997), The Water Cities Of The Asiatic Archipelago, JATI, Bilangan 3, Ogos 1997. 
(2001), "Pengaruh Timur Tengah Dalam Perkembangan Awal Kesedaran Politik Melayu", dalam Jendela Masa, Kuala Lumpur.

----- (2005), “Islam Hadhari dalam pembinaan tamadun masa kini”, Pemikir, bil. 39 \& 40, Januari-April-Jun 2005.

----- (2008) Pendekatan Malaysia Dan Indonesia Dalam Menangani Perkembangan Aliran Pemikiran Islam: Satu Analisis Perbandingan, Jurnal Jati, v. 13.

-----(1980), “ The Terengganu Inscription As The Earliest Known Evidence Of The Finalisation Of The Jawi Alphabet ", dalam Federation Museums Journal, v. 25.

----(1987), "Ruba'i : Pengaruhnya Di Dalam Kesusasteraan Melayu”, Cendekia Kesusasteraan Melayu Tradisional, Kuala Lumpur : Dewan Bahasa dan Pustaka.

-----(1988), "Patterns Of Islamization In Malaysia 1890s-1990s : Exemplars, Institutions And Vectors ”, Journal Of Islamic Studies, v. 9, no. 2.

-----(1994), Gerakan Anti Penjajahan Di Malaysia 1511-1950 : Pengaruh Agama Dan Tarikat, Kuala Lumpur: Penerbit Kintan.

-----(1998), "The Role Of Makka-Educated Malays In The Development Of Early Islamic Scholarship And Education In Malaya", Journal Of Islamic Studies, v. 9:2.

-----(1999), Falsafah Alam Semesta Di Nusantara, Kuala Lumpur: Utusan Publication.

-----(2000), “Kebudayaan Melayu Dan Islam Di Nusantara : Satu Analisa Pengkaedahan ”, dalam Seminar Hukum Islam Semasa 111 Peringkat Kebangsaan 2000, Anjuran Jabatan Fiqh dan Usul, Akademi Pengajian Islam Universiti Malaya, pada 7-8hb. November 2000.

-----(2001), Merekonstruksi Tamadun Melayu Islam; Ke Arah Pembinaan Sebuah Tamadun Dunia Alaf Ketiga, Kuala Lumpur.

-----(2003), “Analisis Sejarah Dakwah Dan Jalinan Intelektual Rantau Malaysia-Indonesia”, dalam Zulkiple Abd. Ghani (ed), Jaringan Dakwah Malaysia-Indonesia, Terbitan Jabatan Pengajian Dakwah dan Kepimpinan, UKM dan Universitas Muhammadiyah Sumatera Utara (UMSU), Bangi.

-----(2004), Pemugaran Semangat Patriotisme Untuk Pembangunan, Sintok : Penerbit UUM.

-----(2005), Citra Islam dalam pembentukan manusia Melayu moden di Malaysia : Suatu analisa, Jurnal Pengajian Melayu, v. 15.

-----(2005), Isu Pendekatan di dalam Pengajian Syariah di Malaysia : Satu Telaah Awal, Jurnal Syariah, v. 13, bil. 1.

-----(2009), Pembangunan Sains Dan Teknologi Di IPTA Islam Di Malaysia : Satu Analisis Sejarah, Jurnal ESTEEM, v. 5, no 2.

-----(2010), Pembaharuan Pemikiran Hukum Islam Di Indonesia, JATI, Volume 15, December 2010.

-----(2010), Wacana Falsafah Sains : Sejarah Dan Pemikiran, Pulau Pinang : ISDEV USM.

----(2011), Tradisi Intelektual Melayu-Islam : Daripada Metafora Kepada Saintifikisme, Jurnal Melayu: The Muslim World Journal (Edisi Khas).

-----(2013), Islam Dan Kearifan Tempatan Di Alam Melayu: Analisis Kritikal, JATI, Volume 18, December 2013.

Abd Moqsith Ghazali, (2007), Mengubah Wajah Fiqh Islam, dalam Abd Hakim dan Yudi Latif (eds.), BayangBayang Fanatisme: Esai-Esai Untuk Mengenang Nurcholish Madjid, Jakarta: PSIK (Universitas Paramadina).

Abd. Jalil Borhan, (1996), Sumbangan Ulama Dalam Perkembangan Islam Di Alam Melayu, Jurnal Syariah, v. 4, bil. 2.

Abdul Halim el-Muhammady, (1992), "Dakwah dan kesannya dalam kehidupan masyarakat Melayu tradisional", dalam Dinamika Dakwah, Suatu Perspektif Dari Zaman Awal Islam Hingga Kini, Kuala Lumpur: IPI. 
Abdul Kadir Muhammad, (1996), Sejarah Penulisan Hukum Islam Di Malaysia, Kuala Lumpur: Dewan Bahasa dan Pustaka.

Abdul Rahman Abdullah, (1982), Pemikiran Umat Islam Di Nusantara, Kuala Lumpur: Dewan Bahasa dan Pustaka.

Abdul Rahman Aziz, (2004), Falsafah Pembangunan, Sintok: Penerbit UUM.

Abdul Rahman Embong, (2003), "Pembangunan Dan Kesejahteraan: Agenda Kemanusiaan Abad Ke-21", Syarahan Perdana Jawatan Professor, Pada 26 September 2003, Bangi: Penerbit UKM.

Abdul Rahman Haji Ismail, (1995), "Nasionalisme Melayu Dan Nasionalisme Melayu Setanah Melayu: Satu Perbincangan Tentang Soal Permulaannya", dalam Isu-Isu Pensejarahan (Esei Penghargaan Kepada Dr. S. Suntharalingam), Pulau Pinang.

Abdullah Alwi Haji Hassan, (2001), "Adat Melayu Mengikut Perspektif Perundangan Orang Islam Di Malaysia”, dalam Adat Melayu Serumpun, Kuala Lumpur: Dewan Bahasa dan Pustaka.

Abdullah Ishak, (1982), Pendidikan Islam Dan Pengaruhnya, Kuala Lumpur: Dewan Bahasa dan Pustaka.

Abdullah Mohd. Said, (2003), "Prosedur Dan Pelaksanaan Penilaian Dampak Sosial “, dalam Mohd Razali Agus (ed), Penilaian Dampak Sosial, Kuala Lumpur: Utusan Publication.

Ahmad Kamal Abdullah, (1988), Unsur-Unsur Islam Dalam Puisi Melayu Moden, Kuala Lumpur: Dewan Bahasa dan Pustaka.

Akh. Minhaji, (2003), Masa Depan Pembidangan Ilmu Di Perguruan Tinggi Agama Islam, Jogjakarta: Percetakan ar-Ruzz.

Amir Santoso, (2007), "Radikalisme Dan Terorisme Di Indonesia", dalam Mohd Izani Mohd Zain (ed), Demokrasi Dan Dunia Islam: Perspektif Teori Dan Praktik, Kuala Lumpur: Penerbit UM.

Amran Kasimin, (1987), Perbendaharaan Kata Arab Dalam Bahasa Melayu, Bangi.

Azyumardi Azra, (1999), Renaisans Islam Asia Tenggara: Sejarah Wacana Dan Kekuasaan, Bandung: PT Remaja Rosdakarya.

Bagoes Wiryomartono, (2012), Historical Notes, Concepts, and Evolution Of Urbanism In The Malay World, JATI, Volume 17, December 2012.

Chamhuri Siwar, (2002), "Paradigma Pembangunan: Meneliti Hubungan Pertumbuhan Ekonomi, Penglobalan, Kegawatan Ekonomi Dan Pembasmian", dalam Misran Rokimin (ed), Falsafah Dan Peradaban Pembangunan, Bangi : Penerbit UKM.

Charles Tisdall, (1916), "Ideas Of Mohammedan Malaya”, The Missionary Review Of The World, v. xxxiv.

Che Su Mustaffa, (1996), "Penerimaan Idea-Idea Pembangunan Di Kalangan Masyarakat Melayu: Satu Analisis Teori Difusi", dalam Ahmad Fawzi Mohd. Basri (ed.), Nilai Orang Melayu, Sintok: Sekolah Pembangunan Sosial, UUM.

D.G. E. Hall, (1968), A History Of South East Asia, London: St. Martins Press.

Faisal Ismail, (1997), "Studi Islam Di Barat, Fenomena Menarik”, Yudian W. Asmin (ed.), Pengalaman Belajar Islam Di Kanada, Yogyakarta: Titian Ilahi Press.

G.P. Means, (1969), The Role of Islam in the Political Development in Malaysia, Comparative Politic, v. 1, no. 2.

H. Syahrin Harahap, (1999), Islam; Konsep Dan Implementasi Pemberdayaan, Yogyakarta: PT Tiara Wacaana Yogya.

Haedar Nashir, (2007), Gerakan Islam Syariat: Reproduksi Salafiyah Ideologis Di Indonesia, Jakarta: PSAP.

Hamedi Mohd Adnan, (2006), Penerbitan Malaysia-Indonesia: Mengukuhkan Jaringan Penerbitan Serantau, Kuala Lumpur : Penerbit UM. 
Hamid Fahmy Zarkasyi, (2004), Tantangan Sekularisasi Dan Liberalisasi Di Dunia Islam, Surabaya: Penerbit Khairul Bayan.

Hashim Musa, (2004), Pemerkasaan Tamadun Melayu Malaysia Menghadapi Globalisasi Barat, Kuala Lumpur: Penerbit UM.

Hassan Ahmad, (2004), "Bahasa Dan Pemikiran Melayu: Tradisi Dan Kesinambungan", Worawit Baru @ Haji Ahmad Idris (eds.), dalam Pemikiran Melayu: Tradisi Dan Kesinambungan, Kuala Lumpur: DBP.

Husin Mutalib, (1990), Islam and Ethinicity in Malay Politics, Singapura.

Ibrahim Abu Bakar, (1994), Islamic Modernism in Malaya, Kuala Lumpur.

Idris Zakaria, (1999), Intelek Eropah Dan Penentangan Terhadap Agama, Al-Maw'izah, bil. 7.

Isabella Bird, (1967), The Golden Chersonese And The Way Thither, Kuala Lumpur.

Ismail Mat, (1997), "Pengajian Syariah : Hubungannya Dengan Adat Arab Dan Keadaan Di Malaysia”, Dinamisme Pengajian Syariah, Kuala Lumpur.

Ithnin Abdul Jalil, (2001), "Pemikiran Saintifik Orang Melayu Melalui Peribahasa", dalam Yaacob Haron Kosmologi Melayu (ed.), Kuala Lumpur: APMUM.

John Esposito, (1996), Islam and Democracy, Oxford.

Lili Yulyadi Arnakim \& Ibnu Hamad, (2010), Islamophobia ad Its Discontents: The Reduction Of Muslims' Self Confidence In The Information Age, JATI, Volume 15, December 2010.

Louay Safi, (1998), Asas-Asas Ilmu Pengetahuan: Satu Kajian Perbandingan Kaedah-Kaedah Penyelidikan Islam Dan Barat, Terj. Nur Hadi Ihsan, Kuala Lumpur.

M.B. Hooker (1976), The Terengganu In Malayan Legal History, JMBRAS, v. XLIX, part 2.

M. Rajantheran, (2001), Amalan Kultus Devaraja Di Asia Tenggara, JATI, Bilangan 6, Disember 2001.

Mahayudin Haji Yahya, (1999), Masyarakat Madani Dalam Kerangka Teori Masyarakat Umran, Jurnal Pendidikan Islam, v. 8, bil. 4.

Meor Ahmad Noor Mior Hamzah, (2001), Konsep Sempadan Negeri Dalam Masyarakat, JATI, Bilangan 6, Disember 2001.

Mohamad Abu Bakar, (2001), "Pengaruh Luar Dan Pengislaman Dalam Negeri: United Kingdom Dan Eire Dalam Kebangkitan Semula Islam Di Malaysia", dalam Mohammad Redzuan Othman (ed.), Jendela Masa: Kumpulan Esei Sempena Persaraan Dato' Khoo Kay Kim, Kuala Lumpur: Penerbit Universiti Malaya.

Mohamad Raduan Mohd Ariff dan Shaharil Talib, (1995), Penulisan Dan Realiti Seiarah Asia Tenggara: Satu Persoalan, JATI, Bilangan 1, September 1995.

Mohammad Redzuan Othman, (1994), The Middle Eastern Influence On The Development Of Religious And Political Thought In Malay Society, 1880-1940, Tesis PhD untuk University of Edinburgh, 1994.

Mohd Hazim Shah Abdul Murad (2005), "Epistemology Colonial: Satu Analisis Ciri Dan Kesannya", dalam Mohamad Daud Mohamad (ed.), Pascakolonialisme Dalam Pemikiran Melayu, Dewan Bahasa dan Pustaka: Kuala Lumpur.

Mohd Mizan Aslam, (2009), The Thirteen Radical Groups: Preliminary Research In Understanding The Evolution Of Militancy In Malaysia, JATI, Vol. 14, December 2009.

Mohd Natsir Mahmud, (1997), Orientalisme: Al-Quran Di Mata Barat (Sebuah Studi Evaluatif), Semarang.

Mohd. Anis Md. Nor, (1990), The Zapin Melayu Dance of Johor: From Village to a National Performance Tradition, tesis PhD, University of Michigan. 
Mohd. Sarim Mustajab, (1982), “Gerakan Islah Islamiyyah di Tanah Melayu: 1906-1948”, dalam Malaysia : Sejarah Dan Proses Pembangunan, Kuala Lumpur.

Mohd. Taib Osman, (1989), Malay Folk Beliefs: An Integration Of Disparate Elements, Kuala Lumpur: Dewan Bahasa dan Pustaka.

Mohd. Yusof Iskandar, (1982), "Masyarakat Melaka 1400-1511 T.M. Dengan Tinjauan Khusus Mengenai OrangOrang Asing”, dalam Malaysia: Sejarah Dan Proses Pembangunan, Kuala Lumpur.

Muhammad Kamal Hassan, (1996), Toward Actualizing Islamic Ethical And Educational Principles In Malaysia, Kuala Lumpur: ABIM.

Nabir Abdullah, (1987), "Turki Dan Alam Melayu: Tinjauan Terhadap Sejarah Hubungan Keduanya”, Jebat, bil. 15.

Nasir Tamara, (2000), "The Ummah: Rising To The Challenges With Special Reference To Indonesia", Dalam Mohd. Taib Osman (ed.), Islamic Civilization in The Malay World, Kuala Lumpur.

Omar Awang, (1981), "The Major Arabic Sources Which Determined The Structure Of Islamic Thought In The Malay Archipelago Before The Nineteenth Century A.D. In The Field Of Law, Theology and Sufism", ISLAMIKA, v. 1.

Osman Bakar, (1989), "Perkembangan Penting Dalam Pemikiran Sains Masa Kini: Satu Tinjauan Umum”, dalam Osman Bakar (ed.), Islam Dan Pemikiran Sains Masa Kini, Kuala Lumpur: ASASI.

Peter Riddell, (2001), Islam and The Malay-Indonesian World, London.

R.O. Winstedt, (1932), “A History of Malaya”, JMBRAS, V. X

Rahimin Affandi Abd. Rahim, (2000), "Fiqh Malaysia: Suatu tinjauan sejarah", dalam Fiqh Malaysia, Ke Arah Pembinaan Fiqh Tempatan Yang Terkini, Sungai Buloh: APIUM.

Rumaya Juhari, (2004), Pengantar Pembangunan Manusia: Perspektif Ekologi, Serdang, Penerbit UPM.

S. Hossein Nasr, (1990), Traditional Islam in The Modern World, London: Kegan Paul International.

Saleh Faghizadeh. (2004), Sosiologi Sosiologi, Terjemahan Oleh Mohd Fauzi Yaacob, Kuala Lumpur: ITNMB.

Shafie Abu Bakar, (1994), "Keilmuan Islam Dan Tradisi Pengajian Pondok “, dalam Budi Kencana, Kuala Lumpur: DBP.

Shaharil Talib, (1997), The Asiatic Archipelago: History Beyond Boundaries, JATI, Bil. 3, Ogos 1997.

Shaharir Mohamad Zin, (2003), Sains Dan Teknologi Melayu Sebelum Penjajahan Eropah, Melayu/Jurnal Antarabangsa Dunia Melayu, v. 1, bil. 2.

Siti Hawa Haji Salleh, (1987), "Kesusasteraan Hikayat Sebagai Suatu Genre: Suatu Perbincangan Berdasarkan Hikayat Ismayatim”, dalam Cendekia Kesusasteraan Melayu Tradisional, Kuala Lumpur: DBP.

Toto Suharto, (2003), Epistemologi Sejarah Kritis Ibn Khaldun, Yogyakarta: Fajar Pustaka Baru.

Victor Tanja, (1982), Himpunan Mahasiswa Islam: Sejarah Dan Kedudukannya Di Tengah Gerakan-Gerakan Muslim Pembaharuan Di Indonesia, Jakarta.

Walid Saif, (1995), "Human Rights and Islamic Revivalism", dalam Religion, Law and Society: A Christian-Muslim Discussion, Geneva.

William Roff, (1980), The Origins Of Malay Nationalism, Kuala Lumpur: Oxford University Press.

Yusri Ihza Mahendra, (1994), Studi Islam Di Timur Dan Barat: Pengaruhnya Terhadap Pemikiran Islam Di Indonesia, Ulumul Quran, 3, v. 3.

Zaini Ujang, (1989), Tinjauan terhadap pendidikan bersepadu: suatu sorotan dalam pengajian kejuruteraan alam sekitar, Jurnal Pendidikan Islam, v. 2, bil. 1. 